\section{Thirty-year secret revealed}

\section{London}

THIRTY-Two years after the event, the Soviet news agency Tass last week carried a report of the nuclear explosion at Kasli, near Chelyabinsk in the Urals, in September 1957. This is the first official disclosure of the accident - although, by 1961, West European and US defence circles were well aware that some such incident had occurred.

As far as the world scientific community was concerned, it was Dr Lev Tumerman (in Nature) and Dr Zhores Medvedev (in his book Nuclear Disaster in the Urals) who, in the 1970 s, first drew attention to the disaster and its aftermath. Much of the evidence was based on discreet reports in Soviet journals about the dispersion of radioactivity by migratory birds.

According to Tass, the details of the explosion have been revealed by Boris Nikipelov, the first deputy minister of "Medium Machine Building" - the cover name for the ministry responsible for both the civil and military nuclear industries. The incident, he said, was a chemical explosion in a tank containing radioactive wastes. As a result, a radioactive 'trail' was formed, $105 \mathrm{~km}$ long and 8-9 km wide. The discharge was about 2 million curies, Nikipelov said, that is, 0.04 times that of Chernobyl. There were no casualties, but 10,000 people had been "urgently RESEARCH IN INDIA

\section{New centre for theoretical research New Delhi}

A CENTRE for advanced scientific research is to be set up in Bangalore and named after Jawaharlal Nehru, India's first prime minister, whose centenary is being celebrated this year. The $\$ 16$ million centre will be structured along the lines of the international institute for theoretical physics at Trieste in Italy.

Professsor C N R Rao, director of the Indian Institute of Science (IIS), also in Bangalore, is to act as president of the Nehru centre which, he says, "will be devoted to scientific research at the highest level in frontier areas". It will set up its own facilities for theoretical work and will have access to the workshop and laboratories of IIS for experimental work.

The centre has been registered as a nonprofit society with the primary objective of providing an excellent climate for research and acting as a national and international forum for free exchange of ideas through workshops, seminars and summer schools. It will have a full-time faculty as well as honorary and visiting positions. Rao hopes the new centre will attract Indian intellectuals now drawn to Trieste.

K. S. Jayaraman evacuated" from the contaminated zone.

Because the waste tank had been sited at a facility for the development of nuclear weapons, he said, the disaster had never been reported in the press. By 1978, "economic activity" had been restored to over 80 per cent of the contaminated zone, he said, and the rest had been converted into a "reserve". For the past 15 years, the

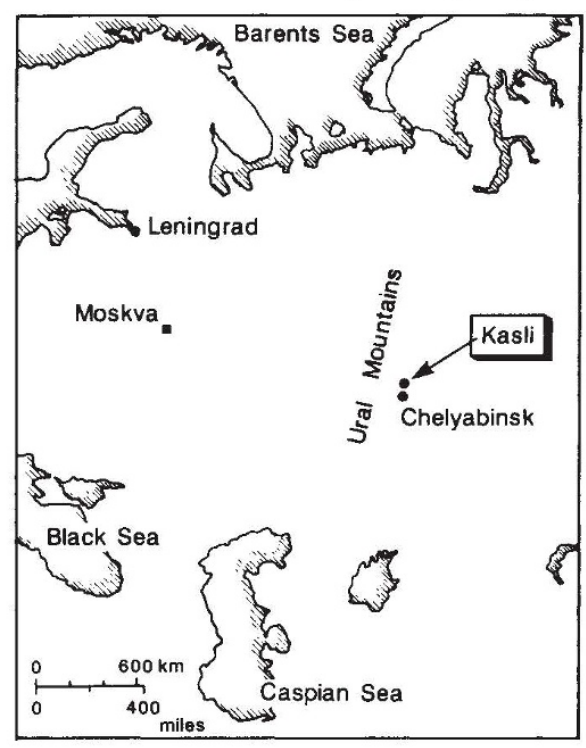

radiation situation had been assessed by experts as "safe".

Nikipelov's revelations have been made as a response to a campaign in Chelyabinsk against a proposed nuclear power station. Nikipelov admitted that some water reservoirs in the area had been contaminated by radioactivity since 1957 , but said that the choice of the area for a power station was "not accidental". The power station, he said, would evaporate the water, thus purifying the reservoirs. Moreover, a commission of independent experts is analysing the safety of the proposed nuclear station and the site's suitability.

This application of glasnost to the Urals disaster has come when there is increasing concern about the Soviet Union's safety record. Since the lifting of reporting restrictions on accidents three years ago, the Soviet media have reported a long sequence of civil and military disasters on land, sea and air.

During the past few months, however, there has been growing criticism of the Soviet record in rescue work. Why, the new generation of investigative reporters ask, does the Soviet Union not have the life-saving facilities available in the West?

Following the disaster on the TransSiberian railway earlier this month, the weekly Literaturnave Gazeta published an interview with the Rector of the Baskkir Medical Institute, who advocated the establishment of special training courses in post-disaster rescue work. A few weeks
Japan's blue sky grows even bigger

\section{Tokyo}

IMAGING and manipulation of materials at the sub-micrometre to atomic level feature in three new ERATO (Exploratory Research for Advanced Technology) projects just announced by the Research and Development Corporation of Japan.

ERATO, which is funded by the Science and Technology Agency, supports out-ofthe-ordinary research by joint teams of young researchers from universities and industry. It received high praise in a recent assessment by the US National Science Foundation. Each project runs for 5 years with a budget of \$2-3 million per year.

Akira Tonomura of Hitachi Central Research Laboratory near Tokyo heads the "electron wavefront" project which will observe materials and magnetic fields in three dimensions at the sub-micrometre level using electron holography. Tonomura's group recently succeeded in holographic imaging of tiny magnetic fields (fluxoid quanta) attached to superconductors. The research is expected to contribute to development of next-generation high-speed electronic devices, such as quantum flux parametrons (another subject of study under ERATO).

Masakazu Aono of the Institute of Physical and Chemical Research continues ERATO's taste for exotic project titles with his "atomcraft" project, also intended to help develop new electronic devices. Using a scanning tunnelling microscope, his team will try to create new semiconductor materials by implanting individual atoms on the surface of materials. And Joh-E Ikeda of the National Institute of Agrobiological Resources will head the "genosphere" project to observe the movement and distribution of chromosomes in living cells with the aim of understanding genetic disease and ageing. David Swinbanks

earlier, Gavrill Popov, newly elected to the Congress of People's Deputies as representative of the Union of Scientists' and Inventors Societies, had castigated the Soviet authorities in connection with the loss of the submarine Komsomolets and for valuing the hardware above the lives of those who operate it. Humanitarian considerations apart, he said, this is also uneconomic, given the cost of training personnel.

There are now fears that the various commissions appointed to investigate the causes of accidents are programmed to concentrate on human error rather than to consider safety procudures themselves. Yet, according to an article in the transport-workers journal Sredneaziatskaya mequstral (Central-Asian trunk route), current operational and safety instructions are such that they could, in reality, lead to a "fire by the rule book".

Vera RIch 